\title{
Role of Teachers in Digital Instructional Era
}

\author{
Happy Fitria \\ Universitas PGRI Palembang, Indonesia \\ e-mail: happyfitriamufly@univpgri-palembang.ac.id \\ Suminah \\ SD Negeri Palembang, Indonesia \\ e-mail: suminah@gmail.com
}

Article History: Received on 17 July 2020, Revised on 21 July 2020, Published on 27 July 2020

\begin{abstract}
The birth of a digital knowledge-based community brought major changes in everything. The role of teachers in learning in the digital age requires the expertise of teachers to implement appropriate solutions to various problems and adapt to changing environments. This change requires a new orientation in education that emphasizes creativity, initiative, innovation, communication and cooperation. In the digital age, teachers are needed to be able to keep up with the times, can play various roles as change bearers, learning consultants; who have a high sense of humanity and morals, and social sensitivity, and are rational and honestminded, so that they are able to work well in a dynamic educational environment. This article discusses the role of teachers in the digital age in learning that is thought to influence vision, responsibility, social sensitivity, logical ability and teacher honesty. All of this boils down to the role of teachers in the digital age as agents of change and learning consultants. The teacher becomes a bridge of revolution by making himself as motivator which moves students to accessible learning resources.
\end{abstract}

Keywords: Agent of Change; Digital Age; Knowledge-Based Community

\section{A. Introduction}

The worrisome reality that occurs in our world of education is the progress of the times is not directly proportional to the progress of the teacher. We also still witness the contrasting reality between teacher and student. Students are already advancing in the digital climate, while teachers are still struggling with the textual tradition. Teachers still use a lot of 80's products now, while students use contemporary products. As a result, students differ radically from teachers, because there are many discrepancies here and there.

The development of information and communication technology is very fast in the past decade. This development is certain to touch, and even give birth to a new orientation in all areas of human life, both social, cultural, economic, political, legal, and education. There has been a shift from the era of knowledge, to the era of information and communication. The transition from a knowledge-based community to an information-based and communicationbased community has brought dramatic changes, especially in terms of how information is constructed into knowledge that can be quickly and widely communicated to all citizens, so that no citizen is isolated in information. 
Being a teacher in the $21^{\text {st }}$ century is different from a teacher in the $20 \mathrm{~s}$. In the digital era as it is today, the existence of a teacher is no longer seen solely from his charisma (Karim and Sugiyanto, 2006). More than that, how a teacher is able to communicate and adapt in the direction of the hands of the times. Teachers in the digital age are demanded to be able to innovate and be creative, because the learning system of the 80 s is no longer accepted by today's students.

Tapscott (1997) mentions that due to the development of internet technology and advances in digital technology that has been accelerated, information and knowledge are temporary and brief. Temporary knowledge requires constant renewal, development and improvement of personal abilities. This progress fundamentally influences the world of education, from the perspective of knowledge to how it is taught in front of the class. This also certainly affects the world of teacher education and education personnel, especially how teacher competencies must be oriented towards the development of information and communication technology and today's digital society.

Bastian (2002) further reveals changes in place of learning, the transition from the analog era to the digital era. In the digital age, the learning environment must be harmonized with the use of information and communication technology, such as the internet and cyber net, which allows learners to learn independently, dynamically and not be bound by only one place and one source of learning, not even dependent on the teaching teacher, but students can learn from many teachers, various sources in cyberspace.

Therefore, all elements of teacher competency tend to treat students based solely on the experience, abilities, knowledge and learning resources of a teacher, or in short measure the potential and ability of students only with the brain of a teacher is not relevant (Ministry of Education and Culture, 2003). But in this dynamic digital era teachers must apply the concept of multy channel learning that treats students as dynamic learners who can learn anywhere, anytime, from anyone, from various sources anywhere. In this case the teacher should act as a facilitator who shows the competencies that must be possessed by students, and opens opportunities for students to be able to learn from various digital learning resources in the global world.

Progress in learning can be adjusted to the needs depending on the availability of access to knowledge and information, which can now be obtained easily and quickly, in a mouse click. This new orientation will have a positive influence on the progress of student's creativity and imagination. In addition, student's critical and analytical thinking skills are expected to be improved, for example by honing their ability to find and identify things quickly in cyberspace. All of this is ultimately expected to improve the competitiveness of the learners themselves. Next it will be discussed about some new reorientation of learning that is considered to affect vision, responsibility, social sensitivity and logical ability, and teacher honesty. All of this leads to a reorientation to the new role of the teacher as an agent of change, knowledge renewal and learning consultant.

The role of the teacher in learning focuses on construction, search and discovery; previously education was interpreted as something that is one-way, which requires the delivery of information by an expert and the acquisition of knowledge that has been prepared, by students. In this case, a teacher is considered an expert who has the answers to each question, so he has full authority. On the other hand, students are always regarded as passive students, 
whatever recipients are taught by the teacher. Bennett (1993), in this era of digital ICT, a new orientation in education is needed that emphasizes the active construction of students through the search for various kinds of information and other resources that are useful for their lives in various situations. This new orientation focuses on learning activities that require students' self-motivation and self-regulation. This is needed in the context of constructing knowledge and experience that can be applied in the particular context that students face. To obtain this knowledge requires active participation in personal development through interactive education and its application, not merely by "absorbing" passively the knowledge that has been designed by others.

The teacher's role in learning that emphasizes creativity and initiative, conventional education tends to display the ability of individual manuals capable of completing the given task. Learners who follow the habits and prescribed paths, use the resources provided by the teacher effectively, and are within the limits that have been designed, are considered to achieve the best results in this methodology.

Buchori, Mochtar (1995) for those who are looking for new things with various choices do not benefit in this regard. This fact is often found and closely related to the social environment which has a hard and rigid structure. This, of course, is incompatible with the current global environment, that is, environments with rapid and rapid development, environments with challenges that are full of unexpected things and involve many things in a wide range. What is needed in this context are people with a high level of competence, creative, full of initiative and intensive people to provide innovative solutions to increasingly complex challenges.

The teacher's role in learning emphasizes interaction and collaboration; people who have reached a high level of specialization with a variety of professions, need broader interaction and cooperation in solving problems. Unfortunately learning designed by teachers still tends to meet the needs and expectations of individual students, for example through planned interactions between students and computer is not yet meeting the demands in the learning environment of today's global digital era. The learning model used tends not to succeed in creating dynamic interactions, both collaboration between students, students and teachers, and students with various learning resources. Cher-Ping and Lee-Yong (2006) interactive and collaborative learning are expected to be able to enrich the learning experience by providing opportunities for students to learn through giving real problems with various perspectives from various aspects, and most importantly, experience sharing and living together in the community.

Teacher's vision; the current paradigm in education has shifted from the teaching paradigm to the learning paradigm. This means that education is no longer about how to convey knowledge and information to students, but about how to help students to find and find information themselves and then help students to construct and create useful knowledge for themselves. The teacher is no longer responsible for the knowledge stored in the minds of students, but how students are able to build knowledge independently (Geddis, 1993). This does not mean the teacher is a passive helper, but is active in the construction process, for example through the creation of a learning environment that adheres to the principle of multichannel learning. In today's global digital era, this should be a clear vision for teachers, how to treat students in learning. 
Teacher moral responsibility; the main job of the teacher is of course teaching. In the social sphere, the teacher also has the responsibility in developing students' self-concepts, for example about morality and ethnic diversity. This can be given through the presentation of social norms and prohibited matters, either directly through the educational aspects being taught, or indirectly through examples of application. The rapid development of information and communication technology and the high level of ambiguity in technology provide opportunities for various problems to occur, for example the way in which social interactions act and deviate behavior. One reason is increased isolation for those who interact excessively on the internet and consequently can reduce interactions between individuals. Furthermore, the possibility of negative consequences regarding secrecy and secession caused by global access, results in the weakening of social norms. The rest of the issues must be discussed or at least be realized, the conditions in the world of education where much interaction is centered on information and communication technology.

Teacher's social sensitivity; in digital knowledge-based communities, there is an emphasis on financial values as well as economic values on knowledge. For example, in developed countries where the digital community is developing very rapidly, there has been a marked decrease in human sensitivity in courses on campus, especially in the hard sciences. This is not so true of science that is focused on application in everyday life. It must not be forgotten in developing originality and imagination, that is, one must instill a sense of humanity and social sensitivity. The application of digital ICTs in education should not reduce this. This is a challenge for teachers in today's global digital world. For this reason, teachers need to be literate people in digital matters so that they are able to understand and be prepared with the high-tech environment that surrounds them, and which will be the things they touch directly in the world of work. Teacher digital literacy not only means the ability to collect, select, refine and process information, but also to assess and determine the credibility of information. In certain cases the results of improvement and processing can differ from one another depending on the social sensitivity of the teacher. Therefore the digital community needs teachers who are literate, digitally, and also sensitive, socially. Social sensitivity in this case is the ability to acquire cultural knowledge, as well as sensitivity to work successfully in the rapidly changing field of education.

Reorienting the ability of logic and honesty of teachers; teachers must have the ability to provide logical reasons in the field of science being taught, by building expertise, and renewing it in accordance with the latest developments on an ongoing basis. In addition, the teacher must have the ability to use real examples related to student life and connect with the subjects being taught. Teachers must be responsive not to make students feel bored by only delivering the material in the same direction as planned. But teachers must increase creativity about how students learn to construct knowledge, for example how to create a learning environment that allows students to learn actively and independently from a variety of learning resources, which allows students to build their competencies as a whole, from basic competencies to high level competencies (Sudiarta, 2007). In addition, in the midst of overwhelming information and digital learning resources that can be accessed quickly and broadly, the teacher must be able to be a pioneer of honesty in learning, for example honest by showing the source of digital teaching materials used, honestly that he has not accessed certain digital information that is needed, and so on. Based on the four points in the global digital society, logical consequences can be derived from the role of teachers in today's global digital society. In this case the teacher can have at least three important roles in global digitalbased education, as a carrier of change, knowledge reformer, and learning consultant (1) 
change carrier; change is the eternal thing in life. Change management not only means passive response to these changes but also how one can actively and intensively plan changes. Lehtinen (2006), in this context the role of the teacher must move from the 'answer provider', that is someone who processes and presents the knowledge needed to deal with change, to be a 'carrier of change', ie a person who helps students in finding the knowledge needed to deal with change, and help them to be able to actively manage their personal development strategies. In other words, the role of teachers in the era of digital knowledge, overcoming the potential shock of change, helping students begin a new vision for the future, motivating leadership for them to be able to help themselves in starting their respective roles, and helping them to be able to continue development programs self; and (2) knowledge reformers, the development of information has been largely decentralized since the era of computer development. The increasingly rapid digital network technology followed by the 'principle of information disclosure' allows people to exchange information and share many sources.

Teacher challenges in the digital age; teachers still use a lot of 80's products, while students use contemporary products. As a result, students differ radically from teachers, because there are many discrepancies here and there. We know that students now no longer fit the $20^{\text {th }}$ century education system. However, praxis in the field, teachers still does not understand this. Many of our teachers are very slow to pursue the pace of education modernization. What happens then is students are able to receive information quickly from various multimedia sources, while many teachers often provide information slowly and from limited sources. Students like to see pictures, listen to music and view videos first before seeing the text, while the teacher gives the text first. Students like to do together activities at the same time, such as completing assignments while listening to music from a laptop, while teachers tend to want to do only one thing at a time.

Students want to access multimedia information hyperlink randomly, while teachers prefer to provide information in a linear, logical and straightforward manner. Students like simultaneous interaction with many people, while teachers want their students to work independently. Students like lessons that are relevant, interesting and can be used immediately (instant), the teacher wants to follow the curriculum and meet standardization. This phenomenon seems to be a bitter pill that we must swallow together. Stretching the virtual world that is currently more loved by our students, it makes teachers need to rethink to arrange a teaching system that is relevant, innovative and adaptive.

Strategy to overcome challenges; the education system is still trapped in structuralbureaucratic authority must be immediately addressed. A teacher's creativity and innovation must be raised immediately. Digital age teachers must not follow a standard and rigid curriculum. Because, the reality of the many learning systems that take place, teachers are still struggling with what is being triggered by the government, where when teachers teach only fixes on rigid and mechanistic curriculum targets. Thus, we find many types of curriculum teachers, that is, teachers who see the benchmarks of success centered on quantitative figures obtained in evaluation alone. This phenomenon certainly gives an understanding that the existence of teachers from one side will experience a threat, because teachers will lose their jobs and are abandoned by their students. But on the other hand, teachers actually get a lot of opportunities if they are able to improve their professionalism and capabilities. In other words, if teachers have not been able to fully enter the digital age, they can become a bridge of revolution. By making themselves as motivators, they move 
students to learning resources that can be accessed. As a dynamic agent, they monitor students in order to develop their creativity and imagination. As an evaluator and justifier, they can assess and give notes, additions, treasury, and so on the findings of students.

\section{B. Methods}

In writing this scientific article, we used the literature study method. The literature study method uses references such as books, journals, proceedings, theses, and dissertations. Each writing source is referred to in the bibliography in accordance with the author's alphabetical name. Literature review is a list of references of all types of references cited and developed with various definitions or theories with explanations and elaborations that can be accounted for in accordance with the bibliography listed.

\section{Results and Discussion}

The new paradigm in the development of education in Indonesia, for example through the Inherent network (Indonesia Higher Education Network) by higher education, and Jardiknas by the Ministry of National Education (Sudiarta, 2007). This has replaced the principle of information closure which is under the authority of certain people. The creation of knowledge by some creative people is at its peak and must give way to the knowledge itself to be shared by people in the network, so that they are able to share ideas based on their own creativity and imagination.

In this changing environment the role of the teacher should not be partial in the pockets of the network of knowledge; but rather the knowledge reformer that provides navigation or guidance on useful sources of knowledge. Therefore in the digital community teachers should not teach knowledge separately, but rather teach discovery methods where and in what ways information and resources can be obtained, and teach ways to process knowledge and apply it to solve problems found in daily life; (3) learning consultants, future teachers are teachers who are experts in their fields. They play a very important role as teach consultants who diagnose various problems faced by students, as well as providing methods that help learning activities. For this role the teacher needs knowledge and skills to match, discover, develop and apply various learning methodologies. Specifically, in using various digital learning resources, teachers need to be literate in the digital world, have the ability to search, evaluate, improve, process and use digital information.

Some things that include digital literacy include the ability to share learning outcomes with others, as well as building and maintaining various cyber communities. Digital literacy is an absolute prerequisite for the development of the digital world and the vitality of digital life, and is also one of the fundamental abilities to help future young people interact in cyber space. Teachers with digital literacy play a very important role as teaching consultants to help students in obtaining information, navigating information and sharing information.

Sanjaya (2006) there are seven roles of teachers in learning in the digital era (1) teachers as learning resources; the teacher's role as a learning resource is related to the teacher's ability to master the subject matter. So when students ask questions, with a quick and responsive response, the teacher will be able to directly answer them in a language that is easily understood by their students; (2) the teacher as a facilitator; the role of the teacher in providing services to students to make it easier for students to receive subject matter. So that 
Volume 1 (1) 2020

E-ISSN: 2723-6919

learning becomes effective and efficient; (3) teachers as managers; in the learning process, the teacher has the role to take full control of the climate in the learning atmosphere. Described like a captain who holds the steering wheel of the ship, which brings the way the ship to the road that is safe and comfortable. The teacher must create a comfortable and conducive classroom atmosphere. So students can receive learning comfortably; (4) the teacher as a demonstrator; acting as a demonstrator means that here is not going to the streets to demonstrate. But what is meant here is that the teacher is a person whose role is to show attitudes that will inspire students to do the same, even better; (5) the teacher as a guide; His role as a mentor, the teacher is asked to be able to direct the students to be what they want. But of course, the teacher must guide and direct to be able to achieve the goals and dreams of the student; (6) the teacher as a motivator; the learning process will succeed if students have motivation in themselves. Therefore, the teacher also plays an important role in fostering motivation and enthusiasm in students to learn; (7) teachers as elevators; after doing the process.

\section{Conclusion}

Teachers should play various roles as change bearers, learning consultants; who have a high sense of humanity and morals, and social sensitivity, and are rational and honest-minded, so that they are able to work well in a dynamic educational environment in the digital era.

\section{E. Acknowledgement}

We would like to express our special thanks and gratitude to Principal of SMP Negeri 5 Prabumulih, Rector Universitas PGRI Palembang who gave us the support to do this wonderful project. This project was funded independent. Secondly, we would also like to thank our friends who helped us a lot in finalizing this project within the limited time frame.

\section{REFERENCE}

Bastian, A. R. (2002). Reformasi Pendidikan: Langkah-Langkah Pembaharuan dan Pemberdayaan Pendidikan Dalam rangka Desentralisasi Sistem Pendidikan Indonesia [Educational Reform: Steps to Reform and Empower Education in the context of the Decentralization of the Indonesian Education System]. Yogyakarta: Lappera Pustaka Utama.

Buchori, M. (1995). Transformasi Pendidikan [Education Transformation]. Pustaka Sinar Harapan.

Bennett, N. (1993). Knowledge Bases for Learning To Teach. Dalam N. Bannett \& C. Carre (Eds.), Learning to teach (h. 1-17). New York: Routledge.

Cher-Ping, L., \& Lee-Yong, T. (2006). Using ICT Tools to Engage Students in Higher-Order Thinking Skills. Singapore: Nanyang Technological University and River Valley Primary School.

Geddis, A. N. (1993). Transforming Content Knowledge: Learning to Teach about Isotopes. Science Educational, 77, 6, 575-591. 
Journal of Social Work and Science Education

Volume 1 (1) 2020

E-ISSN: 2723-6919

Karim., \& Sugiyanto, S. (2006). Menampung Anak Usia Sekolah: Antara Target dan Kemampuan [Accommodating School-Age Children: Between Targets and Capabilities]. Prisma No. 2. Th. V. Jakarta. LP3S.

Lehtinen, E. (2006). Using ICT as Catalyst for Change in The Education. University of Turku.

Ministry of Education and Culture. (2003). Seri Kebijaksanaan Depdikbud: Sistem Pengadaan, Pemanfaatan dan Pembinaan Guru [Ministry of Education and Culture Policy Series: Teacher Procurement, Utilization and Coaching Systems].

Sanjaya, W. (2012). Strategi Pembelajaran: Berorientasi Standar Proses Pendidikan [Learning Strategies: Education-Oriented Process Standards]. Jakarta: Kencana

Sudiarta. (2007). Pemanfaatan Teknologi OSS dalam pengembangan E-Kampus, makalah disampaikan dalam seminar nasional Indonesia Go Open Source dalam meningkatkan daya saing Bangsa [Learning Strategy: Standards-Oriented Education Process Utilization of OSS Technology in the development of E-Campus, paper presented at the national seminar Indonesia Go Open Source in improving the competitiveness of the Nation]. Denpasar 24-25 May 2007.

Tapscott, D. (1997). The Digital Economy: Promise and Peril in The Age of Networked Intelligence. New York: McGraw-Hill. 